\title{
Sustainability in Hunting Licence Systems of Japan and South Korea
}

\author{
Arthur Müller
}

\begin{abstract}
This paper compares the different terrestrial hunting (licence) systems of Japan and South Korea. In order to test their sustainable resource use the silvicultural model and categories by Josef Hackl, Felix Heckl, Martin Forstner, Wolfgang Lexer, and Friedrich Reimoser have been adapted and modified to the circumstances of these two nations. Sustainability will be analysed according to three columns of ecological, economic, and socio-cultural sustainability. The multidisciplinary theoretical approach to sustainability discourses includes the theories of public goods, property rights, and co-management strategies, based on Garrett Hardin's controversial essay The Tragedy of the Commons. Hardin's resource exploitation dilemma has been refuted many times. The working hypothesis is therefore based on a bottom-up approach of decentralisation and subsidiarity mainly based on the assumptions of Elinor Ostrom and Fikret Berkes, in which the preservation of local and therefore context-bound knowledge plays a significant role in the sustainable management of impure public goods like game. The paper seeks to compare current laws on hunting, weapons, wildlife, and environmental protection as well as to take a look at existing local hunting customs and the historic reasons for their disappearance.
\end{abstract}

Keywords: licence hunting, three columns of sustainability, commons, local knowledge

Prae Müller, Arthur. "Sustainability in Hunting Licence Systems of Japan and South Korea." In Vienna Journal of East Asian Studies, Volume 7, eds. Rudiger Frank, Ina Hein, Lukas Pokorny, and Agnes Schick-Chen. Vienna: Praesens Verlag, 2015, pp. 165-196. https://doi.org/10.2478/vjeas-2015-0006 


\section{Introduction}

The hunting systems in Japan and South Korea are known as licensed systems. When hunting rights are controlled by a state or country, and anyone can purchase a hunting licence to hunt certain types of game in certain areas, one speaks of a hunting licence or patent system (Deutsches Jagd Lexikon 2012). In contrast, in Austria, Germany, and most of the Organisation for Economic Cooperation and Development (OECD) countries the hunting ground, territory, or Revier system is widespread. This binds hunting to specific hunting districts where the landowners either possess the right to hunt as holders, or they may lease their hunting rights to other persons. The United States, Japan, Spain, and Italy use the same licence systems as South Korea, whereas in Switzerland there is a combined system (Byun 1998: 1). Each of these hunting systems is different and involves a series of closely related legal, environmental, economic, biological, and cultural factors.

This paper will compare the different management strategies that control access and rights of use in these two hunting economies. It shall also examine to what extent institutional and legal frameworks are in agreement with sustainable development, international ecological policy, and resource management. The aim is to compare the sustainability of use sectors, to identify the strengths and weaknesses of the different hunting systems, and to develop possible future strategies of sustainability. The strategies of sustainability can be understood as theoretical concepts which can offer practical guidance to ethically correct approaches of a single hunting activity (hunting plan) or a hunting system (hunting concept). ${ }^{1}$ In Central Europe the terms 'ethical hunting' or 'huntsman like' are often used to describe the proper way of hunting, which is not necessarily mentioned in laws. These ethically correct procedures often go beyond legal regulations and are in close contact with local awareness of the sustainable use of resources and animal protection (Haug 2004: 51). Sustainability is always connected to a balancing act between the economic use of natural resources and protection of the interests of different parties. Communication between the often discordant actors in the hunting system is a central aspect of establishing a sustainable approach in hunting territories and along their borders. It is important to take into account regional circumstances as well as hunting activities and to respond to regional and local level problems according to the concept of subsidiarity (Ebner 2005: 208). Hence, local knowledge should be in accord with hunting activities (Berkes, Folke and Gadgil 1995: 285). Positive factors that encourage and improve communication between hunters and

1 Ethical requirements for hunting activities should be, if possible, established in the hunting law by a commitment to nature and animal protection. The integration of ethical hunting into the overall ecological system means the balance of interests of farmers and landowners, foreign and local hunters (Wirtz and Wolf 2003: 19). Therefore, social acceptance of sustainable hunting requires a regional frame of reference (Hackl et al. 2006: 77). 
rural populations are employment opportunities for the rural population, economic cooperation, protection and conservation of rural heritage, promotion and coordination of (hunting) tourism, landscape maintenance, up to date hunting facilities, and the enforcement of animal rights. According to the Intel Group European Union (EU) modern hunters act like interpreters and mediators between local communities and legal institutions in order to teach society to establish a healthy relationship with nature (Ebner 2005: 124, 222). Sustainable use should be understood as an instrument of nature conservation, which has to fulfil the intentions of modern animal welfare (Hackl et al. 2006: 20-21).

The scope of this paper includes the actual hunting activities in Japan and South Korea, but also their indirect and external influences on agriculture and forestry, tourism, landscaping, ${ }^{2}$ and other land use sectors. The main theme, sustainability, is divided into three sections which together represent a possible framework for sustainability in hunting systems. The ecological, economic, and socio-cultural columns interact closely with each other and therefore cannot be viewed completely separately (Mauerhofer 2008: 498). The emphasis in the ecological sphere is mainly on wildlife itself; primarily game animals, indirectly also on smaller species. On the ecological column, the conservation and improvement of wildlife habitats, harmful, endangered and migratory wildlife, and temporal and spatial restrictions of hunting are in the foreground of this research. Ensuring economic viability and profitability is a major goal of economically sustainable hunting (Hackl et al. 2006: 9, 10, 25, 26, 73 ), be it marketing of shootings or venison, hunting tourism, ${ }^{3}$ or hunting dog breeds - the aspirations for sustainable use of resources are the bridge between ecology and economy (Ebner 2005: 178). 'Sustainable development' should not be synonymous with sustainable exploitation, rather it refers to the eco-friendly and socially responsible use of resources. Just as much biomaterial should be extracted as the ecosystem can reproduce naturally (Wissenschaftlicher Beirat der Bundesregierung Globale Umweltveränderung 1999: 14). Socio-culturally sustainable hunting is based on the hunting of game which is able to reproduce in the wild. Sustainable use aims at considering the limits of the ecological carrying capacity and the functions of the particular ecosystems, with the intention of

2 The fragmentation of the landscape through roads, railways, settlements, agricultural zones, and industrial zones has significant influence on the shifting position of wildlife habitats. Above all, populations of rare and timid species are negatively affected by the limitation of their natural habitats. The animals are mostly not adapted to their small, newly created habitats and can easily be driven to extinction by incorrect landscape planning. In order to protect these animals, territorial cross-border cooperation and participation in small- and large-scale landscaping is required (Hackl et al. 2006: 43).

3 The challenge for hunting destinations is to foster a long-term optimal use of available scarce resources without damaging natural areas due to overuse or misuse of resources (Horn 2006: 54, 79, 82). Sustainable hunting across borders means that foreign hunters have to make themselves familiar with the ecosystem and the local context of the hunting ground (Wirtz and Wolf 2003: 87). Ultimately, the customer bears the full responsibility for deciding in which hunting activities to participate (Horn 2006: 85). 
balancing between protection and the extraction of resources in a socially fair and steady way (Hackl et al. 2006: 11-21). To do so, especially on the third sociocultural level, the comparison of informal norms and local knowledge seems to be of particular importance. According to Ostrom, the long-term sustainable use of wildlife is usually not included in law, but permitted by local communities and their own protection and sanctioning systems (Ostrom 1999: 241).

\section{Theory}

Natural resources can be regarded as common property if a component of the ecosystem can be used economically by one or more actors (Bromley and Gibbs 1989: 22). Hunting affects a part of the natural resources, such as the genetic diversity of wild species and structure of wildlife populations (Hackl et al. 2006: 19). Natural resources can be either renewable or non-renewable resources (Berkes and Grima 1989: 34). Game can be understood as a renewable resource because populations are basically able to regenerate. However, this does not mean that a renewable resource cannot be exploited and even, in the worst case scenario, exterminated. Impure public goods or commons are determined by rivalry, and exclusion is only possible with high organisational effort or not at all (Berkes and Pomeroy 1997: 466). According to Hardin, the open access to common goods inevitably ends in disagreement between the parties involved and the unconditional exploitation of resources by 'free-riders' until no further profit can be gained. Hardin's solution is the limitation of use under state or private property regimes (Hardin 1968: 1245). He finds ways to limit access to common goods through, for example, licences and memberships which are always regulated under state and private property rights (Berkes and Grima 1989: 44). Hardin notes that access to municipally managed commons through various quasi ritual methods such as lottery procedure, complex electoral systems, a 'first come, first served' principle, etc., can be decided by mutual agreement of users among themselves only if the resources are held as private or state property. Hardin sees himself in the tradition of Thomas Robert Malthus on the topic of the growing global population, arguing for a limitation in the rising number of users. Hardin draws on Georg Wilhelm Friedrich Hegel's 'Freedom is the recognition of necessity' (Hardin 1968: 1248). He claims that the human being is basically selfish and therefore acts according to egoistic interests. For these assumptions Hardin's arguments have been refuted, especially by Ostrom. The main objection levelled at Hardin is that he does not differentiate sufficiently between municipal administration of and public access to the commons, thus ignoring the power of local knowledge which is often traditionally embedded in the long-term communal use of natural resources (Berkes and Farvar 1989: 8). 
The social phenomenon of hunting involves potential conflict between different groups of game resource users (Hackl et al. 2006: 19). Historically, however, there are some examples in which locally managed resources, through the use of traditional methods, achieved relative long-term success without degrading the ecosystem. A successful example of decentralisation, reintegration of local municipal administration under modern state legislature, and successful comanagement strategies is the Japanese fishing system (iriai 入会), in which all coastal waters with the exception of ports and industrial zones are regulated and managed by the Fishing Cooperative Association (FCA) (Ruddle 1989: 183). Sustainable co-management refers to instances in which authority and responsibility is shared between the state and the local community with the common goals of equitable sharing and strengthening the participation of the rural population. The primary decision making takes place at the local level, rather than at a central department (Berkes and Pomeroy 1997: 475). The complex and varying licensing systems of local communities are regulated partly by informal norms and relationships between members, and partly by communal control and sanction systems which are combined with a legal framework of regulations and restrictions (Ruddle 1989: 168-172). Examples of successful municipal management in fisheries show several similarities with the co-management of forests, lands (iriaichi 入会地), and wildlife in Japan up until 1960 (Berkes and Pomeroy 1997: 476). Today many communities are forced to lease their lands, since they no longer have the staff capacity to continue to manage their resources (McKean 1986: 540). Lands in Japan were historically under municipal management for a long time. One village leader was chosen to be responsible for determining the cyclical use of resources and the period of the game harvest. In mountain villages, the days of regulated collective resource use were called 'mountain-opening days' (yama no kuchi 山の口). Written rules (sonpo 損保) and users' agreements as well as informal, often unwritten, norms formed guidelines to the sustainable use of resources as well as penalties for abuse and refusal to work in the township community (McKean 1982: 66-74). The worst sanctions and social stigma in the sanction systems were ostracism and exclusion from the village community. The ensuing ban on the use of certain resources often meant the loss of any livelihood for the punished person or even his whole family. Only the richest families could afford the burden of ostracism, but generally the fear of being banished prevented people inside the community from breaking the informal laws (Acheson et al. 1990: 10). Punishment was usually enacted in silence. In order to strengthen local accountability at the lowest level, control units were mostly local vigilante groups, so-called 'five-man-groups' (goningumi 五人組). A few cases of abuse of power relating to the activities of these groups are known, but in general the approach provided a rather stable and successful controlling and sanctioning system. Other economic and environmental external factors like poaching and other forms of misuse of resources have shown to 
be more devastating for the community systems than internal factors (McKean 1982: 77-79). The decline of local ownership can be better explained as a result of population growth, the commercialisation of resources, technical changes, and political changes (Bromley and Gibbs 1989: 30). The results of this decline are several forms of misuse of resources through social phenomena such as poaching, wildlife trading, and the disposal of game in enclosures. ${ }^{4}$ These phenomena are usually the result of quasi-open access use rights which are not well defined or controlled.

The sustainable use of a resource depends to a large extent on how ownership and use conditions are allocated in the form of local informal norms and/or formal state laws. While the law should determine who has got the resource, the municipal administration should set rules on the access, sharing, preservation, distribution, decision-making, conflict management, and communication between members, users and co-users. Conflicts of competence between national and local interests which further complicate the consensus of successful institution building are not unusual (Bromley and Gibbs 1989: 24-30). According to the theories described, models of local handling show a much higher potential to keep resources sustainable on a long-term basis with (internal) bottom-up decision making than (external) topdown centralised state administration. An empowered local government is generally in close contact with grassroots democracy, public participation, and bottom-up planning on a local level (Acheson et al. 1990: 13).

Traditional ecological knowledge (TEK) offers biological knowledge and ecological insights for long-term sustainable development and qualitative diachronic data, which differ from quantitative empirical data collected by scientists. However, indigenous resource management should not be automatically equated with noble environmental ethics. Approaches vary considerably according to the specific local context (Wissenschaftlicher Beirat der Bundesregierung Globale Umweltveränderung 1999: 124-126). Hunting methods, hunting rules, hunting bags and popular beliefs handed down from generation to generation can be taken as indicative of the existence of TEK. Therefore, the preservation and modernisation of hunting customs and ethical and moral responsibility towards nature are characteristics of a sustainable hunting system which is adjusted to changing societal conditions (Wirtz and Wolf 2003: 52, 123).

4 The release and disposal of game from enclosures or artificial breeding for the purpose of higher hunting bags cannot be justified by ethical standards of socio-cultural sustainability. In contrast, the capture of endangered species for the purpose of breeding and reintroduction into the natural environment is a desirable and sometimes necessary measure to protect certain rare species. Winter enclosures which are intended to reduce game damage to forests and lands are not a permanent solution to regulate the population and therefore not a sustainable means of wildlife management. Often the argument of population control during winter serves as an excuse to cultivate large bucks and bulls for futurehunting success. Tamed game from enclosures is accustomed to humans and therefore should not be reintroduced into the wild for the purpose of hunting (Hackl et al. 2006: 78-79). 


\section{Methods}

The methodological background is primarily based on the forestry model for examining the sustainability of hunting systems proposed by Hackl, Heckl, Forstner, Lexer and Reimoser. This model is understood as flexible, integrated into overall sustainability strategies, modifiable, and thus applicable to small and large units. Criteria and indicator systems provide scientific assessment tools for testing sustainability aims. The categories are subject to the principles of sustainability which are illustrated in the theoretical part of this paper. These principles are normative formulations of a vision of the ideal state of sustainable hunting systems (Hackl et al. 2006: 21, 31). 45 categories, 15 each on an ecological, socio-cultural and economic column, were created to test the sustainability of hunting systems. On the ecological column, categories mainly concern issues such as the existence of detailed bag lists, bag limits and species lists, the consideration of bottleneck situations, hunting pressure and habitat carrying capacity, measures for vegetation control, culling, and the protection of endangered species, etc. The socio-cultural column deals with topics like the conservation and modernisation of informal hunting norms in hunting traditions and indigene cultures, huntsmanlike shooting requirements, as well as the balance of interests between hunters/hunting clubs and other relevant actors in the hunting system. The economic column discusses issues such as the transfer and marketing of venison, property and tenancy rights for hunting ground owners, the implementation of sustainable hunting tourism, job opportunities in the forestry and hunting industry, yearly expenditures for hunting gear, licences, and game damage measurements, etc. The categories explained in further descriptive detail resemble indicators for sustainability. The categories were further divided into a system of sub-categories which were designed to clarify verifiable characteristics of the categories and were provided with a simple rating scheme. Each subcategory had been assigned a positive value, a neutral value, and a negative one. A positive value indicates sustainable resource management. A neutral value shows that certain changes have to be implemented to guarantee sustainable resource use. A negative value means that a major reorientation is needed in respect of this category. This simple testing model can determine which categories require action to be taken. These categories were analysed in a comparative literature study of legal sources, reports by local hunting actors, scientific and journalistic articles, television reports, documentation, material from hunting associations, expert knowledge from email surveys, and qualitative interviews. The interviews took place in Tōkyō on October 4, 2013 with Komori Shigeki 小森繫樹 and Kusakari Hidenori 草刈秀紀 from the World Wildlife Fund (WWF) and on October 7, 2013 with Koike Shinsuke 小池伸介 and Kaji Kōichi 梶光一 from the Tokyo University of Agriculture and Technology (TUAT). The following section provides an overview of the most relevant features of Japan and South Korea's hunting systems. 


\section{Analysis}

\section{Japan's Hunting System}

During the Edo period 江戸時代 (1603-1868) hunting was already practised for the purpose of pest control. Cooperation between hunting and agriculture ${ }^{5}$ has been of crucial importance to both economic sectors since pre-modern large-scale landscaping and the emergence of matagi 又鬼 culture (Taguchi 2009: 191). ${ }^{6}$ In the Wildlife Protection Law of 1918 hunting is also primarily considered to be a method of population and pest control. Since 1956 the dense forest was re-timbered in the context of large-scale forestation programmes (kakudai zōrin 拡大造林). Due to an economic re-orientation in the industrial and manufacturing sectors most of the monocultures were never deforested. Today, wood is mostly imported from other countries. Thus, the deep woods of Japan offer an optimal habitat, ${ }^{7}$ especially for the reproduction of synanthropic species such as the sika deer and wild boar. Harmful game graze, strip trees, uproot slopes, and regularly damage buds and young trees. Due to climate change, the game moves to higher positions in mountainous areas where it damages the partially endangered vegetation (Knight 2003: 30, 40, 152). Between 1978 and 2003 populations of wild boar have increased by 130 per cent. The populations of sika and serow have increased by 170 per cent during that period (Kaji 2013: 5). In most cases, animal populations are estimated by block and spotlight counts, field damage, and harvest reports (Takahashi 2009: 1960). With the collapse of the agricultural sector for rice farming since the early 1990's and the subsequent increase of abandoned farmland, field damage rose dramatically as more and more wild animals left the forest areas in search of food (Kase 2003: 266). In 2010 abandoned farmland reached its greatest area of 396,000 ha (Kaji 2013: 18). In

5 Funds for agriculture and regional hunting initiatives show a great interest to bring nature in line with the management of rural areas (Ebner 2005: 226). Synergies with land, forestry and hunting strategies are jointly created and an indicator for optimised cooperation (Hackl et al. 2006: 61). Successful and sustainable management of ecosystems and efficient use of resources require a complex network of institutions that are responsible for the management of the system (Dietz et al. 2002: 463).

6 The traditional hunting culture of Northeast Japan shares many similarities with hunting cultures of Northeast Asia as the Ainu アイヌ and Udegeizy Удэгейцы (Sasaki 2009: 94, 95). Matagi in Tōhoku 東北 地方 still practice well-documented traditions. Tabi matagi 旅又鬼 are active throughout the year and hunt mostly deer, black bear, serow, monkey, wild boar, and sika. Sato matagi 里又鬼 are focused on small game hunting only during the cold months of the hunting season (Sato 2009: 9, 29).

7 Various factors such as climate, nutrition, type of terrain, disturbance, etc. affect the quality of habitat for game. Habitat carrying capacity is defined as the maximum number of animals and plants, which can be extracted from the habitat, without suffering lasting changes in biodiversity. Species-, bag limits and lists, as well as other instruments to regulate the quality of habitat are necessary to conserve biodiversity. Institutions that offer programmes for the protection and improvement of habitats in accordance with the interests of local hunting clubs can be seen as an indication of a sustainable resource use utilising the habitat carrying capacity (Hackl et al. 2006: 49). 
abandoned areas game populations are often hardly identified or coordinated. For example, in the Fukushima region boars crossbreed with ordinary domestic pigs and cause heavy agricultural damage in nearby areas. Due to the fear of contaminated game they are no longer hunted (Kusakari and Komori, interview October 4, 2013). Often, game reproduces freely in the absence of natural predators such as the wolf, which was exterminated in the beginning of the twentieth century (Kaji 2013: 8). As the natural landscape of hedges and shrubs between forest and village (satoyama 里 山) is decreasing, it directs ungulates like the sika deer and omnivores such as wild boars and bears from their small, fragmented habitats towards human civilisation. Recently a wild boar made its way to the main train station in Nagano 長野市. In most cases, culling for pest control is mandated by the prefecture and carried out by the local hunting club (ryōyūkai 猟友会). ${ }^{8}$ About 60 per cent of the harvest in 2011 took place outside the predetermined four months of hunting season over the winter (Kaji 2013: 33-34). John Knight claims that culling is mainly carried out for the purpose of financing hunting licences, permits, and club memberships as well as to achieve hunting success outside the regular season (Knight 2003: 41, 81). Takahashi A. Mitsuhiko argues that the high incidence of culling can be reduced by involving more experts and scientists in the management and implementation of new wildlife protection laws. Otherwise, culling for vegetation and crop protection might be used as an excuse for personal hunting profits (Takahashi 2009: 1958).

In 1990, the Ministry of the Environment launched a plan for intensified control and monitoring of endangered wildlife and consulted a committee of seven representatives of the largest prefectures. ${ }^{9}$ In the Convention on International Trade in Endangered Species of Wild Fauna and Flora (CITES) the endangered species are listed. According to the wildlife trade monitoring network TRAFFIC, cross-border wildlife trade between Japan and East Asia peaked during the 1980s. Osaka and Kobe were the biggest trading centres in Japan (Nijman 2010: 1101-1114). TRAFFIC and CITES successfully stemmed the problem, but occasionally Japanese custom officials would uncover illegal wildlife imports such as rhino horn or bear gall bladder (Stewart-Smith 1987: 179-187). Without official authorisation from the Ministry of the Environment, commercial and non-commercial trade, import and

8 Game diseases and infections are an indicator of the state of the wild population and the habitat (Sternath 2010: 448). For the implementation of a countermeasure, knowledge about biological relationships among species is necessary. Otherwise areas could remain vulnerable to epidemics in the long term (Horn 2006: 22). Culling is therefore a necessary precautionary measure which can only be justified by a competent authority in exceptional cases, such as the risk of disease, overpopulation, or pest control (Ebner 2005: 123).

9 Endangered species are animals threatened in their long-term survival within their natural range. The respective degree of threat is for example listed in red lists by NGOs. If risk factors, such as declining population density, declining population trends, and habitat losses are taken into account in the hunting concept and plan, potentially endangered species can be correctly identified by their population numbers and protection status (Hackl et al. 2006: 20). 
export of animals, trophies, and organs have been forbidden according to the Act on Conservation of Endangered Species of Wild Fauna and Flora (ACES) since 1992. International cooperation and bilateral agreements on the protection of endangered wild animals have existed within the framework of CITES and the Ramsar Convention with the United States, Australia, China, and Russia since $1980 .{ }^{10}$ In 1974, the first bilateral joint ventures were initiated. The conference topics are mostly habitat carrying capacity and implementation of protection policies. CITES mainly regulates the trade of flora and fauna. In addition to projects with neighbouring countries there is a broad framework on multilateral, international conservation projects in cooperation with Japan. Examples are the cooperation between the Wild Bird Society of Japan (WBSJ) and the Philippines for the protection of endangered wetlands as well as the Asian-Pacific Migratory Waterbird Flyway Network in cooperation with Australia. There have been cross-border cooperation initiatives and joint monitoring projects with Russia since 1996 which are concerned with, for example, endangered birds such as the sea eagle. Since 1992 data on endangered species has been regularly recorded and targeted measures and projects to protect the wildlife have been introduced (ENV 1997: 1-4). According to the Law of Nature Restoration, the basic principles prescribe that intervention in nature should be in harmony with the biodiversity of the ecosystem (ENV 2002: 1). Within the Corridor Plan, so-called 'green belts' were defined to protect and link fragmented zones to large-scale wildlife habitats. The primary objective is the preservation of natural biodiversity according to the principles of the United Nations' (UN) conference on biodiversity in Rio de Janeiro in 1992 (Takayanagi 2002: 303). Furthermore, the Basic Act on Biological Diversity from 2008 emphasises that action intended to protect biodiversity should be strengthened.

Takahashi mainly criticised ACES for the minor changes on statutory measurements and the strong economic focus of the act. Only 81 endangered animal species are listed in ACES, while in the Red List of WWF and the Endangered Species Act (ESA) thousands of them are declared as endangered species. In addition to the Red List, ACES and independent listings of wild animals by NonGovernmental Organisations (NGOs), there is also the Japanese Special Natural Monument (Tokubetsu tennen kinenbutsu 特別天然記念物) which partially compensated for the incomplete documentation of ACES. Takahashi also notes that the annual budget for the protection of endangered species is below the annual budget for game damage reduction and pest control (Takahashi 2009: 1960-1962).

The amount of game damage is so high that the income of landowners cannot cover most of the damage in many of the approximately 40 hunting areas

10 Formally known as The Convention on Wetlands of International Importance, the Ramsar Convention is a treaty which was adopted in Ramsar, Iran, in 1971. It provides a framework for international preservation of vulnerable wetlands (Okamoto 2013: 4). In Japan the convention is protecting about ten wetlands and their partly endangered resident bird species (ENV 1997: 1-4). 
(Takayanagi 2002: 295). In 2010 the damage caused by game in the primary industry reached its peak of 23.9 billion yen (Kaji 2013: 12). 31 per cent of the forest area in Japan is owned by the state and 69 per cent is owned privately. From the private owners, 90 per cent are individual forest owners, farmers, and families. About ten per cent are companies, municipalities, and public associations. For the majority of owners the prime problem is the annually expanding game damage. Due to the rising game damage in the agriculture and forestry sector, methods including scarecrows, conventional fences, electric fences, canopies, and different types of protective constructions for meadows and farmlands were deployed. Some farmers even monitor their fields electronically. Sensors that mimic firearm sounds are intended to scare off wild animals (Knight 2003: 33, 132, 138). Crops such as rice and beets are especially vulnerable to field damage by sika deer, wild boar, and crows (NHK 2012: 11:00). Since many farmers do not measure the game damage on their farmlands and forests, a much higher damage can be projected. Approximately 80 per cent of the shootings were conducted for the purpose of pest control, 20 per cent for risk reduction for humans and dogs (Knight 2003: 46, 130, 170, 177). Detailed bag limits ${ }^{11}$ for all runnable game ${ }^{12}$ species in Japan are stated annually by the prefecture. The bag limits include details on species, sex, horn or anchor shape, characteristics or anomalies, age, and maximum number of harvest. The Environment Ministry sets standards to collect statistics on age, sex, weight, and other characteristics of game. Therefore the hunters have to document every hunting success on a bag list. ${ }^{13}$ Because of the shrinking numbers of hunters in 2012 not even half of the planned harvest was carried out by the hunting population (NHK 2012: 4:00-6:00).

Up until the Second World War most of the population was active in the agricultural sector. Peasants and farmers were the primary source of information on ecosystems (Yoshiaki and Wasao 2003: 5). Since then the number of employees in forestry and agricultural enterprises has been shrinking every year. In 1960, 400,000

11 It is important to define a framework in the form of informal local standards and/or formal laws that strictly define to what extent the resource can be extracted, without exhausting it (Bromley and Gibbs 1989: 28). The purpose of having bag limits approved by the authorities is to set the exact and fair number of game shootings for each species in the hunting list in the respective hunting area (Haug 2004: 66). It is therefore of great importance that a bag limit lists all designated animals for hunting as well as all vulnerable and endangered species under hunting protection (Hackl et al. 2006: 36). The presence of bag limits is an indication of a controlled and therefore sustainable use of wildlife (Sternath 2010: 401).

12 Runnable game in Japan includes 29 species of birds and 20 species of big and ground game. The most commonly hunted species are sika deer, wild boar, bear, duck, and pheasant (Takahashi 2009: 1960).

13 The shooting list is designated as a statistical instrument for the local hunters to measure the harvest in a specific hunting area. It is therefore an opportunity to make statements about wildlife density and population (Wirtz and Wolf 2003: 56). In order to gauge if the hunting activity followed the targets of the predefined bag limits, the shooting list should be as detailed as possible on the age, weight, sex, and special characteristics of the game species, as well as on the date and place of the hunting activity (Hackl et al. 2006: $38)$. 
people were employed in the forestry sector. In 1996, only 80,000 people worked in the forestry industry. Nowadays less than 60,000 people are employed in the forestry sector (Knight 2003: 34). Most of the 47 prefectures of Japan suffer from shortages of skilled personnel. Hence, strained professional hunters often have to undertake the tasks of foresters. Therefore, Takahashi calls for more cooperation with scientific institutions which should be mandatorily involved in the monitoring and management of ecosystems (Takahashi 2009: 1962-1963). The hunting population has decreased every year since 1978 at an average of 3.6 per cent (Igota 2012: 6). Meanwhile, more than 70 per cent of the hunting population is over 50 years old (Kaji 2013: 17). Since 1970 the majority of young people migrated to large urban centres. In most cases, in search of self-realisation, job hunting or in search of a partner, they quit their home villages, leaving the elderly people behind (Yoshiaki and Wasao 2003: 1). The interest in hunting is shrinking and so does the local, context bound knowledge of matagi. The modern matagi see themselves more as sportsmen and recreational hunters as they fulfil their obligations as wildlife managers and rangers (NHK 2012: 05:00). Today, matagi mostly hunt according to modern methods. Modern gear and vehicles are part of the standard equipment. Traditional methods are rarely used anymore (Sato 2009: 28-29). In a few regions, such as Tōhoku some locally specific hunting practices are preserved, especially in the Akita 秋田県 and Aomori 青森市 prefectures (Sasaki 2009: 94). In KatanoKamoike 片野鴨池 in the Ishikawa 石川市 prefecture, an area protected by the Ramsar convention on wetlands, 20 sakaami 坂網 hunters still chase ducks using a traditional net-hunting technique (Okamoto 2013: 1). Every source of young hunters is welcome, but despite a slight increase in the interest of urban so-called 'recreational hunters', the general participation in hunting activities stays relatively low. Less than 0.15 per cent of the population hunts (Kaji 2013: 6). Hunting has become so rare in Japan that the villages where hunters live are often named 'hunter villages' (ryōshi no mura 橅師の村). Most hunters are either recreational hunters or farmers who rarely depend on hunting as a source of income (Knight 2003: 40). The Ministry of the Environment organises information events with lectures on hunting and weapon shows. The aim is to educate the local population and attract young people to hunting. To improve the image of hunting game specialties are often offered freely and cooking recipes are presented. Regardless of marketing, ${ }^{14}$ the economic importance of game in Japanese cuisine remains low outside of Hokkaidō (NHK 2012: 0:30).

Hunting still remains an expensive hobby in Japan. There are one-time minimum charges of approximately 165,000 yen and 198,000 yen in annual tax for owners of a

14 A hunting economy exists if venison is sold directly to the consumer, delivered to the catering trade or to wholesalers (Haug 2004: 182). Furthermore, self-recovery and informal transfer to relatives can be understood as part of a marketing strategy (Hackl et al. 2006: 57). 
hunting licence for guns. Hunters must provide an additional monthly tax of 19,000 yen during each hunting season. If hunters exclusively hunt for birds the tax amounts to 7,000 yen. Every three years an additional test fee must be paid. Also, consumer goods like ammunition and weapon maintenance have to be considered in the annual expenses on hunting. In order to obtain a hunting licence, candidates must be age 18 to possess an air rifle or age 20 to possess long arms. Applicants suffering from mental or physical sickness or drug addiction cannot obtain a hunting licence. Furthermore, people with criminal records are generally restricted from hunting activities (Johnston 2013). In order to obtain hunting permission, membership in a local hunting association is prescribed by the prefecture. The hunting association organises information meetings and appoints hunting leaders. To obtain a hunting licence, a hunting exam ${ }^{15}$ at the regional hunting association is mandatory. The hunting examination tests for wildlife, hunting law, and weapon expertise. A minimum of 70 per cent of the questions must be answered correctly to pass the test. Furthermore, during hunting course education hunters are told when to hunt which sex of game. There is no law which prescribes that bearing animals ${ }^{16}$ are not open for hunting. Nevertheless, between hunters informal rules exist which prohibit hunting animals in critical life stages (Knight 2003: 23, 38, 189).

Access to a hunting licence is considered to be a time intense bureaucratic challenge because the weapon law of Japan is known to be one of the strictest in the world. In Japan licences for firearms (shotguns and rifles), air guns, traps, and nets can be purchased for hunting (Johnston 2013). According to the hunting law of 1918 large-calibre weapons, explosives, poisons, and chemicals are strictly forbidden for hunting purposes (ENV 2012: 3). Handguns are also generally prohibited. Only after ten years of handling a shotgun may a rifle be acquired (Kopel 1993: 2). Disadvantageously, rifles are indeed necessary to carry out intensified hunting on big game which is responsible for most of the damage in agriculture and forestry. ${ }^{17}$ The once great importance of trapping also decreased during the last decades because due to understaffing, time-consuming daily control of trapping systems

15 Hunting exams can vary between countries as well as between prefectures. The subject matter should include laws on game species, weapon use, keeping of hunting dogs and expertise, hygiene requirements and country-specific traditions. Modern hunters should also provide insight into hunting to the local population and act as representative of their hunting club and community (Ebner 2005: 170, 190).

16 In terms of the principles of huntsmanship during the breeding and bearing season, kills on female game should not be conducted. During these seasons hunting pressure should be generally kept to a minimum (Wirtz and Wolf 2003: 122). In the hunting law, closed and open seasons should be adapted to the breeding cycles of runnable game (Haug 2004: 96).

17 In a sustainable hunting system white or melee arms (stabbing or cutting weapons) and firearms (handguns, rifles and shotguns) are necessary for the huntsman's use (Sternath 2010: 333). The hunting laws should underline which weapon is suitable for bagging which species. If this is not the case, inadequate weapon or material standards are required by law. 
cannot be carried out anymore. ${ }^{18}$ The decline in trapping can also be traced back to stricter trade and animal welfare conditions for living animals. Previously, animals were transported mainly alive to keep the meat fresh for a longer time. For economic, hygienic, ${ }^{19}$ and ethical reasons the transportation of living game to a slaughterhouse is forbidden today (Sasaki 2009: 92). The game must be transported properly to a licensed slaughter chamber where it is skinned, disembowelled, and checked for animal diseases by a qualified person. A principle difficulty is that not enough slaughter chambers have been installed by the prefecture and municipalities, so the hunters sometimes have to transport the corpses over long distances before the conservation process starts (NHK 2012: 20:30). The Japanese Agricultural Standard (JAS) seal is the main seal of approval through which customers may inform themselves about the origins of venison. The laws on game meat hygiene vary slightly in different prefectures, but generally venison that is intended for marketing must be processed in a slaughter chamber designated by the prefecture or municipality and has to be marked with a JAS quality seal (MAFF 2012: 14).

In 1999, the Wildlife Conservation and Management Plan of Specific Animals (SWCMP) was introduced by the Ministry of the Environment for precise control and management by the respective prefectures (Takahashi 2009: 1960). The Ministry of the Environment of Japan, founded in 1971 as the Environment Agency and renamed in 2001, employs approximately 1,500 people of whom five persons are in charge of hunting and wildlife management (Kusakari and Komori, interview, October 4, 2013). Since the introduction of SWCMP and the following Koizumi Jun'ichirō 小泉純一郎 government from 2001 to 2006 the government apparatus has been shrinking gradually hand in hand with a policy of decentralisation. Concerning the hunting laws, the tendency towards decentralisation led to a policy where the prefecture or prefectural governor manages the hunting activities, may extend the hunting period, and may relax the ammount of harvest per day (Kaji 2013: 21-23). The exact details of runnable game and hunting seasons vary slightly in each prefecture; therefore hunters must be aware of the specific hunting regulations in their region (Johnston 2013). The prefecture generally employs scientists, forestry experts, and hunting experts to achieve coordination on a scientific basis. The funds for pest control go directly to the hunting clubs which are in turn not sufficiently linked with the representatives of the prefecture. Thus, hunting often happens in an uncoordinated way and without sufficient involvement of the local population (Kaji

18 The overall objective for the sustainable use of trapping methods is that trapping standards, technical regulations for hunting methods, and certification for specific trap types should be considered in the present hunting law in accordance with animal welfare (Ebner 2005: 160).

19 Hunters are responsible for the proper supply, field dressing, and skinning of the game according to food hygiene requirements and regulations (Wirtz and Wolf 2003: 122). As venison spoils quickly careful treatment and processing according to hygiene standards is required (Ebner 2005: 138). For the end user, the production route should be exactly recognisable by authorised quality seals which guarantee the origin of the venison (Horn 2006: 21). 
2013: 36-40). Hunting units are often the first contact and support for the rural population. Governmental decisions are also often based on the information given by local hunting clubs. Therefore, they have to serve as mediators, advisors, and sources of information for the rural population and state officials (Knight 2003: 41). It is necessary to enhance a local feedback function, large-scale territory management, and the clarification of responsibilities between the Ministry of the Environment, the 47 prefectures, and the hunting clubs (Kaji 2013: 36-40).

\section{South Korea’s Hunting System}

During Japanese colonisation (1905-1945) no public hunting was allowed in South Korea. In 1911, the first hunting law was established which allowed only the military and large companies to hunt legally (Pak 1999: 44). As the population often suffered from hunger, poaching took place with traps, snares, and other tools. ${ }^{20}$ During the Korean War (1950-1953) numerous species were reduced down to an existence-threatening level. The rapid industrialisation after the war fragmented and destroyed numerous natural habitats for endangered species. From the Japanese colonisation until the 1970s hunting was de facto only exercised by the military and large companies (CIC 2012). In 1971, the Pak Chŏng-hŭi 박정희 government initiated the New Village Movement (saemaŭl undong 새마을 운동) as a political instrument for mobilising and disciplining the local population on the basic idea of community development. Residents were involved in 'voluntary' community activities for the purpose of strengthening rural self-confidence, social infrastructure, and especially national economic development. A positive effect was indeed the massive building-up of social and economic infrastructure. The increased national and political consciousness of the population as well as the improvement of the employment and living conditions in rural areas are the most significant success stories of saemaŭl undong. Progress in agriculture was the main impetus for the growing secondary and tertiary industry. However, the short-term success at the expense of the natural world finally could not prevent the increasing migration of rural population into urban centres. Despite the strengthening of decentralised decision-making, local self-help landscapes were fragmented and destroyed (Kuhnen 2013). Furthermore, the rural cultural heritage suffered from the heavy economic focus of the movement. Forests were afforested extensively with fast growing tree species crucially supported by the NGO Forest For Life (FFL). In 1982, international cooperation with Germany in the field of forestry was promoted by the

20 The presence, extent, and ecological impact of poaching strongly depend on social factors (informal control and sanctioning mechanisms) and the legal position of the hunting law. Where poaching activities are not taken into account by the authorities, observed and prevented by locals, rangers, and hunters, they occur more frequently (Girtler 1988: 40-88). 
Forest Works Training Center. Since 1970 the South Korean government together with the Korean Forest Service (KFS) has established four ten-year plans for reforestation programmes. The government's goal was to transform South Korea into the most densely forested country in the world by the year 2050 (Lee and Lee 2005: 1-7). Today, these dense forests provide an optimal habitat for the reproduction of game. As a result of the mainly economically driven plan, largescale enterprises were encouraged, but smaller farmers faced the increased pressure to comply with technical standards (Kuhnen 2013). Rho Paikho claims that the knowledge of local communities today is not sufficient to ensure the ecologically sustainable use of ecosystems. The government neglected the conservation of rural culture, thus traditional knowledge in dealing with nature, ${ }^{21}$ practiced for example by snake catchers and ginseng diggers, got partly lost (Rho 2005: 9). The drawback of the economic miracle was the heavy fragmentation of large-scale habitats for wildlife, due to the construction of roads, cities, and industrial zones. In order to reduce the number of animals dying in traffic 92 wildlife paths, ${ }^{22} 55$ hedge connections and 37 underpasses for the passage of wildlife were constructed by the Ministry of the Environment between 1996 and 2006 (Choi and Park 2007: 390-399). Rho claims that these measures could not undo failures of institution building during saemaŭl undong. The landscape changed dramatically without any consideration of wildlife management. Small farmers and family enterprises, threatened in their existence, could not afford to invest in new technologies to face government competition. Furthermore, the state did not subsidise many small enterprises sufficiently. Therefore, the rapid industrialisation mainly caused the loss of rural cultural heritage such as the hunting culture (Rho 2005: 2-4). The general prohibition of guns and air rifles made it impossible to hunt legally, which is why many people modified or built their own illegal hunting weapons. Soon a large poaching culture and a black market emerged which still exists today.

In 1972, the issues of the conservation of biodiversity as well as the management of wildlife and habitat were first discussed in public. From 1972 to 1982 private hunting was completely forbidden in South Korea. The main reasons for the ban on hunting were heavily reduced or even extinct game species by progressive

21 Sustainable hunting requires comprehensive knowledge and transfer of specific information on the hunting ground. Often traditional knowledge is exclusively kept by local experts (Wirtz and Wolf 2003: 54). Consolidation of agricultural planning, forest rehabilitation projects, forest development plans, deforestation, reforestation, and other conservational and landscaping projects, such as wildökologische Raumplanung (WÖRP), require the active participation of hunters, their participation and contribution of knowledge (Hackl et al. 2006: 63).

22 In order to continue to link the original habitats together and reduce traffic accidents with game species, hunters must be aware of the preservation and creation of game passes. Large enclosures are particularly counterproductive for a natural game trail. Protected paths, underpasses, but also facilities such as salt licks and feeding grounds must be constructed to attract game to use designated game passes. Country planners, wildlife experts, and managers are vital contributors to the identification of potential game passes and the collection of data on average game crossings (Hackl et al. 2006: 46). 
urbanisation, industrialisation, overhunting, and poaching. The government was basically not able to coordinate private hunters. In 1982, the circulating hunting system was established. Licensed hunters were now allowed to hunt on fixed and changing hunting areas or in commercial hunting parks (CIC 2012). Like Japan, South Korea has a licence or patent hunting system in which the hunting rights are fundamentally tied to the state. Thus, each applicant has to take part in a hunting course and pass a hunting examination before he or she gets the permission to hunt on a designated runnable game species during a specific time period depending on the type and value of the licence. Unlike Japan, South Korea established a hunting licence system with changing and fixed hunting grounds. Hunting areas are accessible during an either limited or unlimited period as defined by the Ministry of the Environment (MOE 2013). Most hunting grounds are in use for a period designated by the Ministry of the Environment before they switch. A few hunting grounds are permanently established as a hunting park where local and tourist hunters have the opportunity to hunt all year round. There are three fixed grounds and a hunting park on Cheju Island 제주도, Kŏje 거제 and Koch'ang 고창 which resembles a multifunctional amusement park. Licences can be purchased for a certain time and species depending on how much the hunter is willing to pay (Pak 1999: 44). Furthermore, there is a hunting field called Taeyu Island 대유섬. It is open all year, and hunting tourists and people with no hunting experience are allowed to hunt under the supervision of four specialists (Visit Korea 2013). A certain number of wild game animals per day can be harvested by each hunter (MOE 2013). In total 13 species of birds and four ungulate species are defined as runnable game in South Korea (CIC 2012). A total of 221 species are designated as endangered species by the Ministry of the Environment (Rho 2007: 6). Rho criticised the fact that intensive studies had only been carried out on 33 of these 221 species (Rho 2005: 12). There are no hunting seasons specifically matched to the life cycles of runnable game species, but slight variations between prefectures as to which game species may be hunted on which hunting ground (CIC 2012).

The principle of cyclical use of habitats based on maximum biotic and damagerelated habitat carrying capacity seems reasonable for small and fragmented habitats. However, difficulties arise mainly from the fact that only ten per cent of the area of South Korea is defined as hunting area. Also, the hunting population amounts to less than 0.1 per cent of the total population. South Korea's hunting population represents the lowest proportion of all OECD countries (KR Hunter: 2012). In 1982, 2,233 hunters were active in South Korea. The numbers were increasing every year. In 1992 , the number rose rapidly to 8,588 hunters. In 1995 , the hunting population had already increased to 13,458 hunters. According to the International Council for Game and Wildlife (CIC), due to the increased standard of living and a change in the social acceptance of hunting, the sport has become more affordable and public. The main improvements in legal conditions were the introduction of a cyclic hunting 
system in 1982 and the revised edition of the Wildlife Protection and Management Act n 1997 (CIC 2012). The average age of hunters in South Korea is 50 years, and spans a period of between 30 and 75 years (Shin 2001: 192-194). According to Kim Eui-Gyeong and Jang Ho-Chan, hunting in South Korea is an expensive hobby and attracts mainly affluent customers. A hypothetical study on how much the majority of hunters in South Korea are willing to pay for their hobby has shown that many hunters are unhappy with the situation. There is a need to provide hunting licences and training for the general public at an affordable cost. Also, far more hunting places must be created to include the local population into hunting activities (Kim and Jang 1997: 13). A major problem is that the owners of hunting grounds are often over-burdened with administrative tasks. As a consequence many owners of hunting grounds do not have any interest in the long-term management of wildlife and instead choose to exploit their resources until the hunting ground switches again. Byun Woo Hyuk and Yoon Seongil therefore criticised the licensing system of South Korea for its mainly economic perspective and low understanding of sustainable use of private and public hunting grounds. South Korea possesses 'a hunting system in the early stage' (Byun and Yoon 1998: 286).

According to Pak the biggest weakness of the hunting system is the government's poor efforts to collect basic data on wildlife populations in a regular and adequate manner (Pak 1999: 30). On the homepage of KHMA, tables with wild stocks and growth rates of runnable game animals have been accessible since 2000 (KR Hunter: 2012).$^{23}$ In 1963, South Korea conducted a survey on wildlife for the first time. In 1978, the first systematic study under the direction of the Ministry of Forestry was undertaken. Today's Geographical Information Systems (GIS) studies on the natural resources are referred to as a major success of the recent environmental policy according to Rho. GIS studies are designed to provide information on dynamics, growth, and population of wild animals in South Korea. The aim is to facilitate further strategic approaches on measures protecting vegetation. ${ }^{24}$ In 2007 , a wildlife report on the use and risk management relating to imported, immigrated, released, and unknown species was published for the first

23 'Growth rate' refers to the number of young mammals per female game per year. Game can be properly evaluated and handled depending on rising or falling trends of the populations. Population fluctuations are caused not only by hunting activities, but also due to climatic and other anthropogenic influences. The presence of the statistics on growth rates of all wild animals in a specific habitat refers to the sustainable use of the ecosystem (Hackl et al. 2006: 45).

24 Protective fencing must be constructed to safeguard the most vulnerable plant species affected by browsing and vegetation damage caused by game. Possible solutions are rejuvenating areas of the forest, field boundaries, etc. (Hackl et al. 2006: 41). The hunting should further be adapted to the vegetation in the area and carried out gently in a way which does not damage the habitat. 
time by the Ministry of the Environment (Rho 2007: 12, 26). ${ }^{25}$ Since the strengthening of the Wildlife Protection Act in 2004 two central surveys have been carried out each year by the Ministry of the Environment: the Wildlife Population Census (WPC) and the Winter Migratory Bird Census (WMBC). WPC has been conducted annually since 1967 and is the principal source of statistics on wildlife (Rho 2005: 11). Furthermore, the Ministry of the Environment has been working with organisations from Russia, China, Mongolia, and North Korea to protect over 266 species of migratory birds under the Convention on Biodiversity (CBD) since 2002. The project focuses on intensified cooperation with farmers to reduce game damage due to the installation of artificial grazing fields. Farmers were promoted on the basis of their individual effort to offer buffer zones on their fields for the food supply of migrating birds. The budget of CBD has grown every year since 2002. In 2005 ten local prefectures were already successfully involved in the project. The prior target of the project is game damage reduction as well as the protection of migratory birds. A positive side effect might be to attract tourism to the habitats of exotic birds. Since South Korea became a member of the OECD countries in 1997, bilateral agreements with Australia, Russia, and Japan such as the East-AsianAustralian Shorebird Reserved Network, the North East Asian Crane Site Network, the Migratory Trade Agreement China and the Asia-Pacific Anatidae Reserved Network were strengthened (Lee et al. 2005: 35-48). However, Nial Moores criticised the minimal dedication of the government to international conventions such as Ramsar or the Rio de Janeiro Convention as well as a lack of involvement in international NGOs such as BirdLife International, Wetlands International, Conservation International, and WWF International. The lack of a more global environmental view results in an inefficient hunting system which fails to regularly collect data on endangered species. The species lists are not matched by Red Lists (Moores 2005). ${ }^{26}$ The documentation of species lists, population surveys, and research on habitat quality are not carried out regularly. Rho further adds that only a few national studies on the status of wildlife in South Korea have been conducted.

25 Dealing with unknown, non-resistant or alien species may be different, usually assessed according to the damage and influence they have on the ecosystem (Hackl et al. 2006: 57). Possible negative consequences are loss of species and homogenisation of the species inventory (Wissenschaftlicher Beirat der Bundesregierung Globale Umweltveränderung 1999: 27). Wandering or 'returning' species are defined as those that change their habitats regularly between country boundaries and/or borders of prefectures. In a sustainable hunting system migratory species are recognised, considered part of the natural ecosystem and accordingly tolerated if they do not harm the ecosystem (Hackl et al. 2006: 56).

26 A complete species list is the basis for further guidelines for hunting of individual species and thus a significant statistical tool for recording the impact of hunting activities. The more details according to species, number, age, weight, sex, area, and other features of game that the species list provides, the more suitable it is as a statistical forecasting tool for coordinated interventions in the ecosystem (Hackl et al. 2006: 48-49). 
Due to the poor data collection and expert implementation bottleneck situations, ${ }^{27}$ changes in the ecosystem are hardly taken into account (Rho 2005: 5). In order to minimise the game damage of the main pest game, the dynamics of the wild boar population was observed on the basis of GIS (Byun and Yoon 2007: 78). Vegetation damage is mainly caused by wild boars, magpies, squirrels, and roe deer. From 2004 to 2005 the budget for game damage reduction was almost doubled to 2.5 billion Won. In 2005, the damage to the agricultural industry amounted to 21.6 billion Won. Ch'ae Jong-hyŏn, Yi Min-su, and Pak Tŏk-pyŏng estimated the actual amount to be about ten times higher. With increased government support for pest control since 2005, a slight decline in game damage has been measured. However, in 2007, the total reported game damage amounted to 63.5 billion Won. Primarily the agricultural sector was affected (Ch'ae, Yi and Pak 2008: 3-4). The reporting of game damage stays low, because ten per cent of the reported damage is not replaced by the government.

The prefectures set different priorities on which control measures to use depending on the resident pests. Widely used methods are sirens, barrier tapes, scarecrows, fireworks, control units, the cultivation of plants disliked by pest species, and audible and spotlight warning systems. Ch'ae, Yi, and Pak doubt the effectiveness of some questionable methods of vegetation protection (Ch'ae, $\mathrm{Yi}$ and Pak 2008: 7-27). In addition to vegetation protection measures, outside the hunting season a private culling unit is also regularly hired with the permission of the prefecture. In 1999, the privatised group was suspected of having acted in their own economic interests by feeding wild animals in order to increase the bag during the off-season. Meanwhile, however, all the accusations were refuted according to the homepage of the Hunting Korea Management Association (KHMA) (KR Hunter: 2012). In 2010, about 50 per cent of the harvest was conducted outside the regular winter hunting season of four months. According to the Ministry of the Environment the main justification was pest control. Ch'ae, Yi, and Pak notice that despite growing budgets for the reduction of game damage, the government still insufficiently supports small and mountain farmers. These people mostly cannot afford expensive equipment and therefore suffer heavily from the damage to their crops (Ch'ae, Yi and Pak 2008: 7-27).

Often rural residents receive no weapon permission under the strict gun law of South Korea. Only a limited number of persons have the permission to own or carry weapons. These include professionals in the security sector, sport shooters, rangers, and hunters. After the amendment of the Wildlife Protection and Management Act in 1998 hunting examinations were held for the first time. Previously, it had been

27 Bottleneck situations can occur seasonally, due to overpopulation or certain environmental specifics (Wirtz and Wolf 2003: 36). Bottleneck situations can thus be caused by anthropogenic or natural factors. A sustainable hunting system reacts and responds appropriately to critical situations by taking coordinated measures for intervention. 
sufficient to simply attend the hunting course. Today, the completion of the examination requires regular attendance at lectures and a positive test result. In addition to a hunting licence, a weapon permit given by the local police headquarters is required to possess a weapon. Every five years the certificate must be renewed (MOE 2013). Today's hunting examination involves individual tests in the biological, juridical, political, and systemic understanding of the participants. There is still no test in shooting skills and weapon handling (CIC 2012). Byun and Yoon criticise the still inadequate training of hunters in comparison to other OECD countries (Byun and Yoon 1998: 286). In South Korea licences for shotguns, air guns, nets, and bows may be acquired. Registration at the local administrative authority is necessary. Reasons for refusal include a minor age of less than 20 years, mental or physical handicaps, addictions, criminal convictions, crimes against wildlife and nature conservation, etc. Hunters who have repeated serious offences can be banned for life by their local hunting association. Hunting with vehicles of all kinds, explosives, and methods which unnecessarily torment game are strictly prohibited. Revolvers and pistols are rarely used. Legal firearms are shotguns and air rifles (CIC 2012). Both gun types are not suitable for properly hunting big game. For that reason numerous illegal (modified) hunting weapons are circulating (Byun and Yoon 1998: 294). The KHMA criticised the lack of control of illegal weapons and the outdated Hunting Weapons Act of 1961 which requires urgent reformation (KR Hunter: 2012). About 20,000 hunters who use shotguns and half a million owners of air guns were active in 2012. For security reasons, all weapons are under police custody off season (CIC 2012). Pak is particularly critical of the lack of detection of weapon owners who have a hunting licence. He claims that in 1995 the relatively small number of about 8,000 to 13,000 hunting licences a year seemed far too low in comparison to the total number of about 526,000 registered weapon owners. This might be an indicator that many weapon owners hunt without a licence, so they are in fact poachers. Pak estimates that the illegal possession of weapons amounts to 60 per cent of all weapons in circulation. Not every hunting ground requires a registration or is subject to any control of hunting licences and methods in use. This often results in uncontrolled poaching of endangered species (Pak 1999: 44).

There is still a high demand for certain endangered species in Chinese traditional medicine. Their consumption is said to have special healing, stamina or potencyboosting effects. In 1997 NGOs registered 17,000 businesses which usually sell both legal and illegal game, trophies, and wildlife products. Due to the high demand for the products, illegal import goods from all over Southeast Asia flood the black markets of South Korea. According to Pak 90 per cent of the wildlife products sold in shops stem from animals which were killed illegally. He estimates an annual number of 3,000,000 animals poached per year. The industry is estimated at an annual profit of about 21.6 billion Won. Supposedly, the revenue recorded for taxidermy is estimated to be twice as much. Frequent customers include private 
consumers, but also museums. Pak speaks of a well-established illegal 'poaching industry' because the market prices of the items are clearly defined. A living animal usually is sold for double the price. According to animal welfare organisations the controls are deficient and are enforced only sporadically. The sanctions are mild compared to international standards, and in most cases delinquents just have to pay a fine. Poached wildlife products can be bought easily at most night markets and butcheries. The items are especially used in the field of traditional medicine. Primarily resident and invasive species that are already endangered or nearly extinct are affected. The Wildlife Protection Act of 2004 by the Ministry of the Environment emphasises cross-border cooperation, management of wildlife populations, the establishment of protection areas and increased controls of poaching. In light of the structured black market a total number of between 90 to 120 arrests per year still seems extremely low. Pak claims that annually 1,000,000 traps are set by approximately 20,000 illegal hunters and poachers. In 1997, the Ministry of Forestry confiscated 11,895 illegal hunting tools in collaboration with NGOs. Pak calls for clear declaration of closed areas and seasons, and a tighter control of poaching. Likewise, the penalties should be tightened (Pak 1999: 43, 49, 64, 183). It is still difficult to find evidence for poaching, but a possible solution offered by the Seoul National University operates through a molecular genetic approach which locates the origins of venison on the basis of deoxyribonucleic acid (DNA) traces (An et al. 2007: 59).

\section{Conclusion}

The hunting licence systems and economies of Japan and South Korea still have many obstacles to overcome in order to sustainably manage their game resources. The negative effects of the hunting licence system are the exploitation of game populations by unauthorised users, overtaxing by authorities, and weak local communities with little economic incentive resulting in a low eco-ethical commitment to manage wildlife sustainably in the long-term. Territorial hunting systems might provide a more efficient and long-term way to manage small, fragmented hunting grounds and resources sustainably than a hunting licence system in which access for recreational hunters is less regulated or controlled.

While Japan's hunting system primarily suffers from demographic and environmental problems, South Korea's main challenge is the establishment of an efficient hunting system to control and sanction game damage, poaching, and wildlife trade. Management by rural communities has been weakened in the wake of industrialisation, urbanisation, and fragmentation of landscapes due to transport networks. According to Rho, the communication between the Ministry of the Environment and local communities is characterised by a weak feedback function. 
Local communities are generally not sufficiently involved in the decision making processes of national and local governments (Rho 2005: 1-4). According to the KHMA there is little social acceptance of and dedication to hunting in the countryside (KR Hunter: 2012). Collaboration with NGOs and hunting organisations to link habitats is on the rise, but financial support from the state is still insufficient. Since 2000 an increasing number of recreational hunters have moved to rural areas, but nevertheless the necessary bag limits are far from fulfilled.

Rho warns about the increasing hunting and poaching pressure on natural habitats despite numerous conservation programmes administered by the government. ${ }^{28}$ The main causes of habitat degradation are poaching, overuse, and development syndromes. ${ }^{29}$ Overall, South Korea has much fewer and much smaller protected areas than any other OECD member state (Rho 2005: 1,6). Pak cites the main reasons for the critical condition of habitats as an incorrect hunting policy, lack of supervision, and mainly economically influenced hunting ethics. He argues that in many regions little research is still conducted on the actual habitat carrying capacity (Pak 1999: 44, 72). Rho claims that United Nations Educational, Scientific and Cultural Organisation (UNESCO), Ramsar Wetlands, Migratory Waterbirds Network as well as national protected areas (nature conservation, natural monument, nature park and genetic conservation areas) are insufficient to ensure protection to endangered species and shrinking game populations. Although local governments have determined protection areas since 2005, there are still not enough natural reserves available. 1.84 per cent of the total area of South Korea is preserve area. By 2015, the Ministry of the Environment aims for 5.5 per cent (Rho 2005: 8). In 2004 the Wild Life Protection Act was reinforced by the Ministry of the Environment. According to the newly reformed act, endangered wildlife species and habitats should be systematically protected (Lee et al. 2005: 49). Rho suggests that the master plan for the protection of biological resources and the expansion of protected areas for endangered species of wildlife were the first positive developments in environmental policy (Rho 2007: 12). Furthermore, the growing budget for habitat management measures and the establishment of nearly 30 new hunting areas in all

28 Disturbance of the peace, needs, and habitat of game can cause serious browsing damage and deviant behaviour especially in sensitive stages of reproduction (Wirtz and Wolf 2003: 37). Dormancy periods and zones should be offered to a sufficient extent. Closed seasons reduce the hunting pressure and enable the wildlife to regenerate (Hackl et al. 2006: 52).

29 Overuse syndromes are for example the agricultural overuse of marginal land (Sahel syndrome), overexploitation of natural ecosystems (overexploitation syndrome), environmental degeneration by structural change to traditional farming methods (country flight syndrome), environment degeneration due to extraction of non-renewable resources (Katanga syndrome), environmental degeneration by intensified uncontrolled tourism (tourism syndrome), etc. Development syndromes include environmental degeneration through a rapid economic take-off (Little Tiger's syndrome), urbanisation and environmentally hazardous behaviour in human settlements (Favela Syndrome), expansion of infrastructure and environment pollution (Suburbia syndrome), etc. (Wissenschaftlicher Beirat der Bundesregierung Globale Umweltveränderung: 1999: 33). 
nine prefectures of South Korea might be indicators for a changing view on environment and wildlife issues. Still, only a small part of South Korea's landmass is accessible for public hunting, so the main future sustainability strategies should primarily target the establishment of a subsidised, accepted, controlled, regulated, and sanctioned hunting licence system. Therefore it is necessary to foster locally, regionally, and nationally coordinated cooperation between the Ministry of the Environment, Ministry of Forestry, scientific experts, prefecture officials, local hunting clubs, farmers, and land owners. Comparative research is needed in order to develop a better hunting system in South Korea (Byun and Yoon 1998: 1).

In Japan informal user and co-user agreements between hunters, land owners, and forest owners still remain intact. Due to existing local standards and selfcommitment, a further enhancement of controlling and sanctioning systems is not necessarily required (Ostrom 1999: 89). Most hunting grounds in Japan are privately owned by peasant families and subsidised by the state. The highest authority is represented by the Ministry of Environment (MOE) and the Ministry of Agriculture, Forestry and Fisheries (MAFF) which define general laws on wildlife and hunting conditions. The prefectures set specific rules for the respective area, to coordinate projects and keep in contact with local hunting associations. In return, the hunting associations assist landowners and tenant farmers with their obligations. ${ }^{30}$ If they are not able to fulfil their tasks regarding the reduction of game damage and pest control, the government can implement the necessary supporting measures. The main problem is that hardly any private owners can meet the government requirements on bag limits and pest control, which is why most synanthropic species are culled during off season. However, an efficient hunting system should be able to reach the necessary bag limits during the hunting season, employ enough staff in the hunting economy, and make hunting accessible for a broader part of society. Due to the shrinking population of hunters in Japan there is a risk that old practices of communal oriented handling of resources will not be available in the future. Context-bound, traditional ecological knowledge, such as the transmission, distribution, and modernisation of

30 The forest owner or holder of rights of use can be represented by a single person or corporation. However, the owner or tenant is responsible for employing recreational or professional hunters whose job and obligation is to cultivate and care for the wildlife and habitat. If no marketing of hunting licenses and shootings is fostered by the owner or holder of rights of use, professional hunters are instructed by competent authorities to meet the requirements for wildlife coordination and management. The right to hunt can be awarded to a tenant or several co-holders on an officially designated minimum term for big and ground game hunts. For the lease to owners real estate agents can be employed. The tenant or co-holder has to ensure sustainable hunting within the agreed spatial and temporal boundaries. Duties of the owner or co-owner are among others the timely payment of the agreed rent, game management, and prevention of field damage (Haug 2004: 34, 35, 182). The expenditures are, among other things, hunting rights and basic costs, bag fees, taxes and duties, feeding costs, territory facilities, field damage compensation, and communication with local actors. The benefits include inter alia the sales of venison and the subjective recreational value of a hunting activity. The balance from the perspective of the owner or tenant is positive if the benefits or expenses outweigh the costs (Hackl et al. 2006: 59). 
hunting traditions is no longer preserved. This results in the weakening of decentralised resource management at the grassroots level. According to Berkes and Folke, centralised systems risk loss of and bias to information between the lowest and highest levels. Thus, because of the lack of information and the weak feedback function, state institutions often follow failing environmental politics. A lack of feedback generally results in a poor learning function and slow reaction on ecological changes (Berkes, Colding and Folke 2000: 432). Consequently, it is necessary that the Ministry of Environment (MOE) and the Ministry of Agriculture, Forestry and Fisheries (MAFF) are taking further efforts to financially support the local level, to target actions against environmental problems, and to make hunting attractive to young people. Possible solutions would be data-based integrative, adaptive wildlife management approaches, intensified game population control instead of conservation and protection policies of game species, enhancing campaigns for the marketing structure of venison, as well as opening Japan up for regulated and controlled hunting tourism. Given the overpopulation of pest species a further possibility would be to extend the hunting season and increase the female harvest on some species, as well as to set the licence fee as low as possible. 


\section{LIST OF ABBREVIATIONS}

ACES

CBD

CIC

CITES

DNA

ENV

ESA

EU

FCA

FFL

GIS

JAS

KFS

KHMA

MAFF

MOE

NGO

NHK

OECD

SWCMP

TEK

TUAT

UN

UNESCO

WBSJ

WPC

WMBC

WÖRP

WWF
Act on Conservation of Endangered Species of Wild Fauna and Flora Convention on Biodiversity International Council of Game and Wildlife

Convention on International Trade in Endangered Species of Wild Fauna and Flora

Deoxyribonucleic acid

Minister of the Environment, Japan

Endangered Species Act

European Union

Fishing Cooperative Organisation

Forest for Life

Geographical Information System

Japanese Agricultural Standard

Korean Forest Service

Korea Hunting Management Association

Ministry of Agriculture, Forestry and Fisheries, Japan

Ministry of Environment, Republic of Korea

Non Governmental Organisation

Nippon Hōsō Kyōkai

Organisation for Economic Cooperation and Development

Specified Wildlife Conservation and Management Plan

Traditional Ecological Knowledge

Tokyo University of Agriculture and Technology

United Nations

United Nations Educational Scientific and Cultural Organisation

Wild Bird Society Japan

Wildlife Population Census

Winter Migratory Bird Census

Wildökologische Raumplanung

World Wildlife Fund 


\section{REFERENCES}

Acheson, James M., Fikret Berkes, David Feeny, and J. Bonnie McCay. "The Tragedy of Commons: Twenty-two Years Later.” In Human Ecology, 18/1, 1990, pp. 1-19

An Jungwha, Mu-yeong Lee, Mun-Han Lee, Hang Lee, and Mi-Sook Min. "A Molecular Genetic Approach for Species Identification of Mammals and Sex Determination of Birds in a Forensic Case of Poaching from South Korea." In Forensic Science International. Seoul: Seoul National University, 167/1, 2007, pp. 59-61

Berkes, Fikret, Johan Colding, and Carl Folke. "Ecological Practices and Social Mechanism for Building Resilience and Sustainability.” In Linking Social and Ecological Systems: Management Practices and Social Mechanism for Building Resilience, edited by Fikret Berkes, Carl Folke, and Johan Colding. Cambridge: Cambrige University Press, 2000, pp. 414-437

Berkes, Fikret and Thagi M. Farvar. "Introduction and Overview." In Common Property Resources: Ecology and Community-based Sustainable Development, edited by Fikret Berkes. London: Belhaven Press, 1989, pp. 1-17

Berkes, Fikret, Carl Folke, and Madhav Gadgil. "Traditional Ecological Knowledge, Biodiversity, Resilience and Sustainability.” In Biodiversity Conservation, edited by C.A. Perrings et al. Dordrecht: Kluwer Academic Publishers, 1995, pp. 281-299

Berkes Fikret and A.P. Lino Grima. "Natural Ressources: Access, Rights-to-Use and Management." In Common Property Resources: Ecology and Community-based Sustainable Development, edited by Fikret Berkes. London: Belhaven Press, 1989, pp. 33-52

Berkes Fikret and Robert S. Pomeroy. "Two to Tango - The Role of Government in Fisheries Comanagement." In Elsevier Science Marine Policy, 21/5, 1997, pp. 465-480

Bromley, Daniel W. and Christopher J. N. Gibbs. "Institutional Arrangements for Management of Rural Ressources: Common-Property Regimes.” In Common Property Resources: Ecology and Community-based Sustainable Development, edited by Fikret Berkes. London: Belhaven Press, 1989, pp. 23-32

Byun Woo Hyuk and Seongil Yoon. "Comperative Analysis of Hunting System in OECD Countries." In Journal of Korean Forestry Society, 87/2, 1998, pp. 286-299

Byun Woo Hyuk, So Ra Kim, Won-Myoung Kim, Tae-Mim Kim, and Woo-Kyun Lee. "A GIS Based Study on Spatial Characteristics of Wild Boar Movement." In Forest Science and Technology, 3/1, 2007, pp. 78-84

CIC - Wildlife (International Council for Game and Wildlife Conservation). "Hunting and Wildlife in Korea." 2012, CIC - Wildlife Budapest, http://www.cicwildlife.org/index.php?id=15, accessed December 2012

Choi Tae-Young and Chong-Hwa Park. In Wildlife Vehicle Collision by Increasing the Number of Wildlife Passages in Korea. Seoul: Seoul National University, 2007

Ch'ae, Jong-hyŏn 채종현, Yi Min-su 이민수 and Pak Tŏk-pyŏng 박덕병. "Yasaeng tongmul millyŏb'ŭi hyŏnhwang'gwa hyŏngsabŏp'chŏk taeŭng” 야생동물 밀렵의 현황과 형사법적 대응 [Two Case Studies on Wild Animals Damage and Its Countermeasures]. Seoul: Nongch'onjinhŭngch'ŏng, nongch'onjawŏn'gaebal yŏn'guso 농촌진흥청, 농촌자원개발연구소, 2008

Deutsches Jagd Lexikon. "Lizenzjagdsystem.” November 5, 2012, Deutsches-Jagd-Lexikon, http://www.deutsches-jagd-lexikon.de/index.php/Lizenzjagdsystem, accessed June 2013

Dietz, Thomas, Nives Dolsak, Elinor Ostrom, and Paul C. Stern. "Knowledge and Questions after 15 Years of Research." In The Drama of the Commons, edited by Thomas Dietz et al.

Washington: National Academy Press, 2002, pp. 445-489

Ebner, Michl. Nachhaltige Jagd. Bozen: Verlagsanstalt Athesia AG, 2005 
ENV (Ministry of the Environment Japan). "Wildlife Protection System and Hunting Law.” 1997, Ministry of the Environment - Government Japan, http://www.env.go.jp/en/nature/biodiv/ law.html, accessed June 2013

ENV (Ministry of the Environment Japan). "Law for the Promotion of Nature Restoration.” 2002, Ministry of Environment - Government Japan, http://www.env.go.jp/en/laws/nature/ law_pnr.pdf, accessed June 2013

ENV (Ministry of the Environment Japan). "Summary of Wildlife Protection and Hunting Law." 2012, Ministry of the Environment - Government Japan, http://www.env.go.jp/en/laws/nature/ law_wphm-summary.pdf, accessed June 2013

Girtler, Roland. Wilderer. Linz: Landesverlag, 1988

Hackl, Josef, Felix Heckl, Martin Forstner, Wolfgang Lexer, and Friedrich Reimoser. Sustainable Hunting - Principals, Criteria and Indicators. Wien: Umweltbundesamt GmbH, 2006

Hardin, Garrett. "The Tragedy of the Commons." In Science, New Series, 162/3859, 1968, pp. 1243-1248

Haug, Andreas. Wildlifemanagement und Forstwirtschaft unter besonderer Berücksichtigung der Randbedingungen und Möglichkeiten einer Optimierung jagdwirtschaftlicher Aspekte für Waldeigentümer. Berlin: Tenea Verlag für Medien, 2004

Horn, Sandra. Jagdvermarktung: Die Zielgruppe touristischer Auslandsjäger und das Angebot. Saarbrücken: VDM Verlag Dr. Müller, 2006

Igota, Hiromasa. "History and Status of Hunting and Wildlife Management in Japan." In Wildlife Management System Symposium, edited by Wildlife Management System TUAT. Tokyo: Tokyo University of Agriculture and Technology, December 24, 2012, pp. 5-6

Johnston, Eric. "In Japan, Gun Control is the Norm and Discipline is Rigid." January 29, 2013, Japan Times News, http://www.japantimes.co.jp/news/2013/01/29/reference/in-japan-guncontrol-is-the-norm-and-discipline-is-rigid/\#.UVCghjfm5V8, accessed June 2013

Kaji, Koichi. Distribution, Status and Management of Ungulates in Japan. Tokyo: Tokyo University of Agriculture and Technology, 2013

Kase, Kazutoshi. "Changing Mentality of Postwar Farmers." In Farmers and Village Life in Twentieth-century Japan, edited by Yoshiaki Nishida and Ann Wasao. London and New York: Rouledge, 2003, pp. 244-266

Kim Eui-Gyeong and Ho-Chan Jang. An Estimate of Willingness to Pay (WTP) for a Day-use of a Year-round Hunting Site in Korea by the Dichotomous Contingent Valuation Method. Chinju: Department of Forestry, Gyeongsang National University, 1997

Knight, John. Waiting for Wolves in Japan: An Anthropological Study of People-Wildlife Relations. Oxford: Oxford University Press, 2003

Kopel David B. “Japanese Gun Control.” In Asia Pacific Law Review, 2, 1993, pp. 26-52,

KR Hunter (Korea Hunting Management Association). "Korea Hunting Association.” 2012, Hanguksuryeopgwallihyeophoe Internet Homepage, http://www.khunter.kr/, accessed December 2012

Kuhnen, Frithjof. "Das Beispiel Südkorea.” 2013, http://www.professor-frithjofkuhnen.de/publications/community-development/3-3.htm, accessed December 2013

Lee Deog Bae, Kee Kyeong Kang, Kwang Lai Park, and Myeong Chul Seo. Management of Paddy Fields for the Habitat of the Winter Migrants in Korea. Seoul: National Institute of Agricultural Science and Technology, 2005

Lee Don Koo and Yong Kwon Lee. Roles of Saemaul Undong in Reforestation and NGO Activities for Sustainable Forest Management in Korea. Seoul: Seoul National University, 2005 
MAFF (Ministry of Agriculture, Forestry and Fisheries). Kankei suru hōreitō 関係する法令等 [The Related Laws]. 2012, Ministry of Agriculture, Forestry and Fisheries of Japan, http://www.maff.go.jp/j/seisan/tyozyu/higai/h_manual/h23_03/pdf/ data4.pdf, accessed June 2013

Mauerhofer, Volker. "3-D Sustainability: An Approach of Priority Setting Interests towards a Sustainable Development” In Ecological Economics, edited by Richard B. Howarth. Vienna: Elsevier, 64, 2008, pp.496-506

McKean, A. Margaret. "The Japanese Experience with Scarcity: Management of Traditional Common Lands." In Environmental Review, 6, 1982, pp. 63-88

McKean, A. Margaret. "Management of Traditional Common Lands." In Common Property Resource Management, edited by National Research Council. Washington: National Academy Press, 1986, pp. 533-589

MOE (Ministry of the Environment Korea). "Ministry of the Environment Korea." 2013, Hwangyeongbu Internet Homepage, http://me.go.kr/index.jsp, accessed June 2013

Moores, Nial. "Key Species - South Koreas Most Urgent Priorities for Conservation.” 2005, Birds Korea Homepage, http://www.birdskorea.org/Birds/Key_Species/BK-KS-Key-KoreanSpecies.shtml, accessed June 2013

NHK (Nippon Hōsō Kyōkai). “Close-Up-Gendai.” 2012, Nippon Hōsō Kyōkai, http://veohdownload.blog37.fc2.com/blog-entry-16439.html, accessed June 2013

Nijman, Vincent. "An Overview of International Wildlife Trade from Southeast Asia." In Biodiversity Conservation, 19, 2010, pp. 1101-1114

Nishida, Yoshiaki and Ann Wasao. Farmers and Village Life in Twentieth-century Japan. London and New York: Rouledge, 2003

Okamoto, Hiroko. Saakami-hunter. Katano-Kamoike: Office of Ishikawa-ken Daishoji Duck Hunting Area Cooperative, 2013

Ostrom, Elinor. Die Verfassung der Allmende: Jenseits von Staat und Markt. Tübingen: J. C. B Mohr (Paul Siebeck), 1999

Pak, Ki-sŏk 박기석. Yŏndobyŏl yuhae yasaeng tongmur'e ŭihan p'ihae hyŏnhwang 연도별 유해 야생동물에 의한 피해현황 [A Study on Poaching Wildlife and Its Criminal Encounters]. Sŏul: Han'guk hyŏngsa chŏngch'aeg yŏn'guwŏn 한국 형사 정책연구원, 1999

Rho, Paikho. GIS-based Wildlife Habitat Management Strategies in Korea. Seoul: Korea Environment Institute, 2005

Rho, Paikho. Nature and Biodiversity Management in Korea. Seoul: Korea Environment Institute, 2007

Ruddle, Kenneth. "Solving the Common-property Dilemma: Village Fisheries Rights in Japanese Coastal Waters." In Common Property Ressources: Ecology and Community-based Sustainable Development, edited by Fikret Berkes. London: Belhaven Press, 1989, pp. 168184

Sasaki, Shiro. ed. Human-Nature Relations and the Historical Backgrounds of Hunter-Gatherer Cultures in Northeast Asian Forests: Russian Fareast and Northeast Japan. Osaka: National Museum of Ethnology Japan, 2009

Sato, Hiroyuki. "Ethnoarchaeology of Trap Hunting Among the Matagi and the Udehe: Traditional Hunting Peoples Living Around the Sea of Japan." In Human-Nature Relations and the Historical Backgrounds of Hunter-Gatherer Cultures in Northeast Asian Forests: Russian Fareast and Northeast Japan, edited by Shiro Sasaki. Osaka: National Museum of Ethnology Japan, 2009, pp. 25-47 
Shin, Won Sop. "Environmental Attitudes and Motivations of Korean Hunters." In Journal of Korean Forestry Society. Cheongju: School of Forest Resources, Chungbuk National University, 90/2, 2001, pp. 190-196

Sternath, Michael. Der Jagd-Prüfungsbehelf. Wien: Österreichischer Jagd- und Fischerei-Verlag, 2010

Stewart-Smith, John. The Shadow of Fuji-san - Japan and Its Wildlife. Middlesex: Penguin Books, 1987

Taguchi, Hiromi. “Correlative Significance of Trap-placing and Environmental Differences: Traditional Hunting in Mountainous Areas of Central and Northern Japan." In Human-Nature Relations and the Historical Backgrounds of Hunter-Gatherer Cultures in Northeast Asian Forests: Russian Fareast and Northeast Japan, edited by Shiro Sasaki. Osaka: National Museum of Ethnology Japan, 2009, pp. 47-57

Takahashi, A. Mitsuhiko. "Overview of the Structure and the Challenges of Japanese Wildlife Law and Policy." In Biological Conservation. Toyama: Faculty of Human Development, University of Toyama, 142/9, 2009, pp. 1958-1964

Takayanagi, Atsushi. "Treatments of Forests and Wildlife in Modern Society." In Forestry and the Forest Industry in Japan, edited by Iwai Yoshiya. Vancouver: UBC Press, 2002, pp. 292-307

Visit Korea. "Daeyoo Land (Hunting Field).” 2013, Visit Korea Homepage, http://english.visitkorea.or.kr/enu/SI/SI_EN_3_1_1_1.jsp?cid=266846, accessed June 2013

Wirtz, Hans Gerd and Harald Wolf. Jagd und Nachhaltigkeit an der Schwelle des 21.Jahrhunderts - Chancen und Perspektiven. Weimar: Verlag Rita Dadder, 2003

Wissenschaftlicher Beirat der Bundesregierung Globale Umweltveränderung. Welt im WandelErhaltung und nachhaltige Nutzung der Biosphäre. Berlin, Heidelberg and New York: Springer-Verlag, 1999

\section{INTERVIEWS}

Kaji Kōichi 梶光一 and Koike Shinsuke 小池伸介. Interviewed by author, Tōkyō, October 7, 2013

Kusakari Hidenori 草刈秀紀 and Komori Shigeki 小森繫樹. Interviewed by author, Tōkyō, October 4, 2013 


\section{GLOSSARY}

\begin{tabular}{|c|c|c|}
\hline Ainu & アィヌ & indigenous people of north Japan \\
\hline Akita Island & 秋田県 & $\begin{array}{l}\text { prefecture in the Tōhoku region on } \\
\text { Honshū }\end{array}$ \\
\hline Aomori & 青森 & $\begin{array}{l}\text { city and prefecture on north Honshū } \\
\text { Island }\end{array}$ \\
\hline Chejudo & 제주도 & province and island of South Korea \\
\hline Edo jidai & 江戸時代 & Japanese time period, $1603-1868$ \\
\hline goningumi & 五人組 & five man group \\
\hline iriai & 入会 & $\begin{array}{l}\text { municipal management of fisheries in } \\
\text { Japan }\end{array}$ \\
\hline iriaichi & 入会地 & $\begin{array}{l}\text { municipal management of lands in } \\
\text { Japan }\end{array}$ \\
\hline Ishikawa Island & 石川市 & $\begin{array}{l}\text { prefecture in the Chūbu region on } \\
\text { Honshū }\end{array}$ \\
\hline Kaji Kōichi & 梶光一 & Scholar of Wildlife and Ecology \\
\hline kakudai zōrin & 拡大造林 & $\begin{array}{l}\text { expansive afforestation plan by the } \\
\text { Japanese government in } 1956\end{array}$ \\
\hline Katano - Kamoike & 片野鴨池 & $\begin{array}{l}\text { Bird Sanctuary, wetland in Ishikawa } \\
\text { prefecture }\end{array}$ \\
\hline Koch'ang & 고창 & hunting ground in Kyŏnggi prefecture \\
\hline Komori Shigeki & 小森繫樹 & Fundraising Officer at WWF Japan \\
\hline Koike Shinsuke & 小池伸介 & Senior Assistant Professor TUAT \\
\hline Koizumi Jun'ichirō & 小泉純一郎 & $\begin{array}{l}\text { Prime Minister of Japan from } 2001 \text { to } \\
2006\end{array}$ \\
\hline Kŏje & 거제 & $\begin{array}{l}\text { city located in South Kyŏngsang } \\
\text { province }\end{array}$ \\
\hline Kusakari Hidenori & 草刈秀紀 & WWF Japan Executive Officer \\
\hline matagi & 又鬼 & traditional hunters of northeast Japan \\
\hline Nagano Island & 長野市 & $\begin{array}{l}\text { capital city of Nagano prefecture on } \\
\text { Honshū }\end{array}$ \\
\hline Nippon Hōsō Kyōkai & 日本放送協会 & $\begin{array}{l}\text { Japan's national public broadcasting } \\
\text { organisation }\end{array}$ \\
\hline Pak Chŏng-hŭi & 박정희 & $\begin{array}{l}\text { 1917-1979, third president of the } \\
\text { Republic of Korea }\end{array}$ \\
\hline ryōshi no mura & 猟師の村 & hunter village \\
\hline ryōyūkai & 猟友会 & local hunting association \\
\hline saemaŭl undong & 새마을 운동 & New Village Movement \\
\hline sakaami ryōshi & 坂網猟師 & traditional hunters in Katano-Kamoike \\
\hline sato matagi & 里又鬼 & $\begin{array}{l}\text { traditional hunters active during the } \\
\text { winter season }\end{array}$ \\
\hline satoyama & 里山 & $\begin{array}{l}\text { border zone between mountain foothills } \\
\text { and arable flat land }\end{array}$ \\
\hline sonpo & 損保 & written code \\
\hline tabi matagi & 旅又鬼 & traditional hunters active all year \\
\hline Taeyu & 대유섬 & all-year hunting ground \\
\hline
\end{tabular}


Tokubetsu tennen kinenbutsu

Tōhoku

Tōkyō

Udegeizy

yama no kuchi
特別天然記念物

東北地方

東京

Удэгейцы

山の口
Japanese Special Natural Monument

region on Honshū Island

capital of Japan

native population of the Primorsky Krai and Khabarovsk Krai regions in Russia

'mountain-opening days'; harvest event in mountain villages 